Check for updates

New York, USA

Cite this as: $B M / 2020 ; 370: m 2723$ http://dx.doi.org/10.1136/bmi.m2723 Published: 07 July 2020

\section{Covid-19: Major US medical organisations urge people to wear masks}

\author{
Janice Hopkins Tanne
}

Three major US healthcare organisations have asked Americans to wear masks, practise social distancing, and wash their hands to prevent the spread of covid-19, while the White House rejected giving a national order as cases continued to surge.

The American Medical Association, which represents about half of American doctors; the American Nurses Association, which represents around 4 million nurses; and the American Hospital Associations, which represents about 5000 hospitals and hospital systems, published an open letter on 6 July asking the public "to protect themselves, their neighbours, and their loved ones amid the worst global health crisis in generations." 1

The letter said that these measures, which had led to a decline in infections and deaths, had been too quickly abandoned as states began reopening. "We are now watching as a dramatic uptick in covid-19 cases is erasing our hard won gains. Hospitals in some states are at or nearing their intensive care capacity. Shortages of personal protective equipment and testing supplies continue to pose a threat to healthcare workers and patients alike," it said.

"As physicians, nurses, hospital and health system leaders, researchers, and public health experts, we are urging the American public to take the simple steps we know will help stop the spread of the virus: wearing a face mask, maintaining physical distancing, and washing hands. Covid-19 is not behind us and we must resist confusing reopening with returning to normalcy. Doing so will escalate this crisis and result in more suffering and death."

The White House chief of staff, Mark Meadows, said on the Fox and Friends television programme that President Donald Trump saw mask wearing as a state matter and would not give a national order. ${ }^{2}$ The president does not wear a mask although he recently said he would in a situation where social distancing was not possible.

The US has more than 2.9 million cases and 130199 deaths as of the evening of 6 July, according to the New York Times database. More than 250 ooo new cases were reported during the first five days of July. Cases are surging in Florida, which reported 10059 new cases; Texas, which reported 4431 new cases; and Arizona, which had 3510 new cases (all on 5 July). ${ }^{3}$

Florida does not report state-wide hospitalisations, but Miami-Dade county does, and on 4 July covid-19 patients were taking up $70 \%$ of available intensive care beds and the city was in the "red flag zone" of rising cases. ${ }^{4}$

The mayor of Austin, Texas, Steve Adler, said on CNN's State of the Union, “If we don't change the trajectory, then I am within two weeks of having our hospitals overrun. And in intensive care I could be 10 days away from that." 5

Dallas County leader, Judge Clay Jenkins, said there was "rampant community spread" and told people not to go to restaurants and to avoid places where a mask can't be worn all the time or where social distancing was impossible. ${ }^{6}$

Black and Latino Americans were far more likely than whites to become infected and to die, the New York Times reported, ${ }^{7}$ based on new data it got after suing the Centers for Disease Control and Prevention under the freedom of information law. Latino and black Americans were three times as likely to become infected as whites, and nearly twice as likely to die. The disparities persisted across states and regions and in rural areas, suburban areas, and many big cities.

AHA, AMA, ANA. AHA issue open letter urging public to wear a mask to stop Covid-19 spread. AMA Media relations. 6 July 2020. www.aha.org/press-releases/2020-07-06-aha-ama-ana-issue-open-letter-urging-public-wear-mask-stop-covid-19.

2 Singman B. Mark Meadows says there will not be a "national mandate" on wearing masks. www.foxnews.com/politics/mark-meadows-says-there-will-not-bea-national-mandate-on-wearing-masks.

Coronavirus in the US. Latest map and case count. New York Times. 6 July 2020. www.nytimes.com/interactive/2020/us/coronavirus-us-cases.html.

4 Neal DJ. Third highest single day total, 10 059, pushes Florida past 200000 covid-19 cases. Miami Herald. 6 July 2020. www.miamiherald.com/news/coronavirus/article244011507.html.

CNN Politics. Austin mayor: ICUs will be overrun in 10 days. www.cnn.com/videos/politics/2020/07/05/sotu-adler-full.cnn.

6 Branham D. Dallas Country reports 1062 new coronavirus cases amid 'rampant community spread.' Dallas Morning News. 6July 2020. www. dallasnews.com/public-health/2020/07/05/dallas-county-rports-1062-new-coronavirus-cases-amid-rampant-community-spread.

7 Oppel RA, Gebeloff R, Lai KKR, et al. Racial disparity in cases stretches all across the board. New York Times. 6 July 2020. www.nytimes.com/interactive/2020/07/05/us/coronavirus-latinos-african-americans-cdc-data.html. 
This article is made freely available for use in accordance with BMJ's website terms and conditions for the duration of the covid-19 pandemic or until otherwise determined by BMJ. You may use, download and print the article for any lawful, non-commercial purpose (including text and data mining) provided that all copyright notices and trade marks are retained. 